\title{
1997年鹿児島県北西部地震の地震動の特性 CHARACTERISTICS OF THE GROUND MOTION OF THE 1997 KAGOSHIMAKEN-HOKUSEIBU EARTHQUAKE
}

\author{
松村和 雄* \\ Kazuo MATSUMURA
}

\begin{abstract}
The earthquakes which occurred in the northwestern part of Kagoshima prefecture on March 26 and May 13 in 1997 caused severe damage to some reinforced concrete school buildings and wooden houses. Many ground motion records are obtained by the seismographs of JMA and NIED which settled in high density after 1995 Hyogoken-Nanbu Earthquake. The response spectra of the ground motion of four sites which surround the seismic region are analyzed. The large peak ground accelerations such as $728 \mathrm{~cm} / \mathrm{s}^{2}$ at Izumi or $902 \mathrm{~cm} / \mathrm{s}^{2}$ at Miyanojyo are recorded but did not cause no severe damage of buildings near seismographs. These records contain predominant high frequencies of over $5 \mathrm{~Hz}$. The response spectra of four sites are different by the location to the seismic region.
\end{abstract}

Keywords: Earthquake disaster, Seismograph, Response spectrum, Attenuation curve, Kagoshima prefecture 地震災害、強震計、応答スペクトル、減衰曲線、鹿児島県

\section{1.はじめに}

1997年3月26日17時31分に鹿児島県北西部の紫尾山付近を震源と してマグニチュード; $M=6.5$ の地震が発生して住宅や学校施設に被 害が発生した。その後、M=4 5の余震が十数回発生して被害が应 大し、5月13日にはM=6.3の地震が発生して新たな被害が発生した。 これらの地震により、震源に近い多くの住宅と学校の校舎や体育館 が大きな被害を受けた。

この地方は歴史地震の記録もなく、観測された地震もほとんどな い。このような地震活動度の低い地域での地震危険度、特に再来周 期の長い地震による地震八ザードを考える資料が少ない現状ではこ の地震は貴重な資料である。加えて、同じような規模の地震が50日 後に発生したという例は少ないため、地震で被災した建物の応急対 策を考える場合の参考になる地震である。

この地震は1995年兵庫県南部地震以来の主な被害地震であり、そ の地震を契機として全国に高密度に設置された気象庁と科学技術庁 の強震計により多くの地震動が観測された。これらの強震計は計測 震度の測定が第一の目的ではあるが、高密度に設置されているため 被災地域に近い地震動が得られるので防災や地震工学の面で有効で ある。また、科学技術庁の強震記録はディジタル化されたデータが 直ちにインターネットを通じて公開されるため利用価值が高い。

本論文は今後の地震防災に役立てるためにこれらの強震記録に表 れた地震動の特性を明らかにするものである。

\section{2. 地震と建物被害の概要}

3 月 26 日に $M=6.5$ の地震、 4 月 3 日に $M=5.5$ の最大の余震、 5 月 13 日 にM=6.3の地震が発生し、その後、活動は徐々に収束に向かうとと もに震源が南に移っている。この間、Mが4〜 5の余震が十数回記録 されている。3つの大きな地震の震源情報を表 1 に示す。震央の位 置と余震分布および大破した学校校舎の位置と強震計の位置を図 1 に示す。この地震の断層は確認されていないが、3月26日の地震の 余震分布はほぼ東西方向の直線で、5月13日の地震の余震分布はそ れらと異なる位置に東西方向と南北方向のL字型で両者は異なって いる。従って、2つの地震は別の震源に起因寸ると考えられる。 地震の震源域である紫尾山付近には人家はほとんどなく、建物の 被害は大部分が震源域の周辺で発生した。3月26日の地震による建 物の被害は震源の東側に位置する鶴田町や宮之城町で大きかったが、 5月13日の地震では東側から南側に位置する宮之城町と東郷町と川 内市で大きかった。3月26日の地震では小被害にとどまった建物が5 月13日の地震で大きな被害に至った場合も多かった。表 2 に示寸鹿 児島県の調査によれば、住家は8棟が大破と診断された。これらは 振動とともに地盤による影響も大きかった。しかし、大半は屋根瓦 のずれなど比較的軽微な被害であった。住宅以外では5棟の鉄筋コ ンクリートの学校校舎が大破と診断され、十数棟が中破の被害を受 けた。体育館は1棟が大破したが、多くは鉄骨ブレースのボルトの 破断やシルバークールの接合部の一部破損にとどまった"。

Prof., Dept. of Architecture and Architectural Engineering, Faculty of Engineering, Kagoshima Univ., Dr. Eng. 
表 1 地震の震源情報（Mはマグニチュード）

\begin{tabular}{|c|c|c|r|}
\hline 発 生 時刻 & 震 央 位 置 & M & 梁さ \\
\hline 1997年3月26日17時31分 & $31^{\prime \prime} 58^{\prime} \mathrm{N}, 130^{\prime} 22^{\prime} \mathrm{E}$ & 6.5 & $12 \mathrm{~km}$ \\
1997年4月 3日 4時33分 & $31^{\circ} 59^{\prime} \mathrm{N}, 130^{\circ} 19^{\prime} \mathrm{E}$ & 5.5 & $9 \mathrm{~km}$ \\
1997年5月13日14時38分 & $31^{\prime \prime} 57^{\prime} \mathrm{N}, 130^{\prime} 18^{\prime} \mathrm{E}$ & 6.3 & $9 \mathrm{~km}$ \\
\hline
\end{tabular}

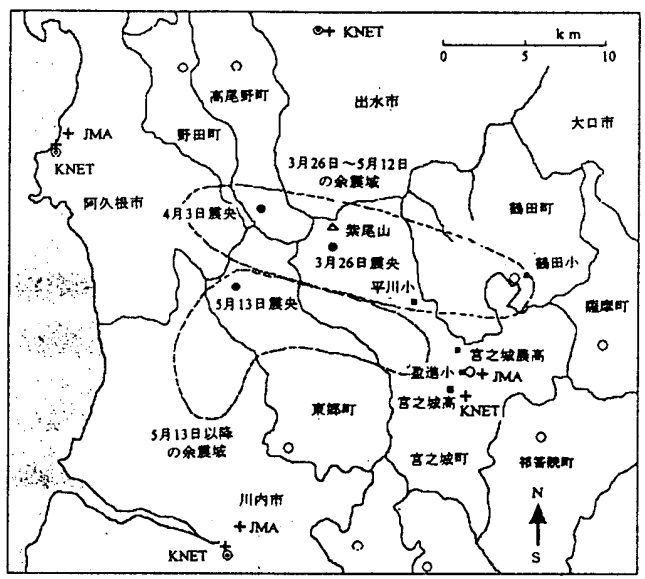

凡 例

震央

十強震計

$\mathrm{J} \mathrm{MA}=$

気象台

$\mathrm{KNET}=$

科学技術庁

口大破した

学校校舎

()市役所

○町役場

図 1 震源の位置と余震分布および大破した建物の位置

表 2 鹿巟島県の住家の被害棟数” (6月13日現在)

\begin{tabular}{|c|r|c|r|r|}
\hline 被害程度 & 3月26日 & 4月3日, 5日, 9日 & 5月13日 & 合 \\
\hline 全 圢 & 4 & 0 & 4 & 8 \\
半 壊 & 22 & 11 & 29 & 62 \\
一部破損 & 2,184 & 200 & 4,944 & 7,328 \\
\hline
\end{tabular}

\section{3. 鹿児島県北西部地域の地震活動}

宇佐美のカタログ3 と気象庁の地震カタログから、この地域で過 去に発生した被害地震およびマグニチュードが $\mathrm{M}>5$ の最近の地震の 震源位置を図2に示す。今回の震源域である鹿児島県北西部では被 害地震や大きな地震が記録されておらず、その周辺の被害地震も少 ないことが分かる。今回の震源域に近い被害を伴った地震としては 約40km東側に群発地震である1968年えびの地震が発生している゙。

最近の地震の傾向を見るために気象庁の震源データから、1926年 から1996年6月までの $\mathrm{M}>2$ で60 $\mathrm{km}$ より浅い微小地震の震源位置を図3 に示す。今回の震源域には1980年までは地震は全くなかったが、そ の後、図に示寸ような微小地震が発生している。1994年2月13日に 今回の震源の北東の $32.07^{\prime \prime} \mathrm{N}, 130.48^{\mathrm{C}} \mathrm{E}$ に $\mathrm{M}=5.7$ の地震が発生してい るので、これらはその影響によるものと考えられる。

このような地震活動が低い地域では地震記録が少なく、一般に地 震危険度も小さい。九州北部や北海道北部のように地震活動が低い 地域で、長い再現期間の地震動あるいは地震荷重を設定するのは難 しい問題であるが、規模的にはどこにでも起こる可能性が高い今回 の地震は今後の地震防災の参考になるものである。

\section{4. 強震記録}

今回の地震では1995年兵庫県南部地震を契機として計測震度の測 定のために全国に設置された気象庁の95型震度計引と科学技術庁のK -NET95強震計 によよって多くの強震記録が得られた。ここでは強震 記録が取得できた、図 1 に示す震源を囲む 4 地点の科学技術庁の強 震観測網 $(\mathrm{K}-\mathrm{NET})$ の記録と気象庁の95型震度計の記録を解析して地 震動の特性を明らかにする。

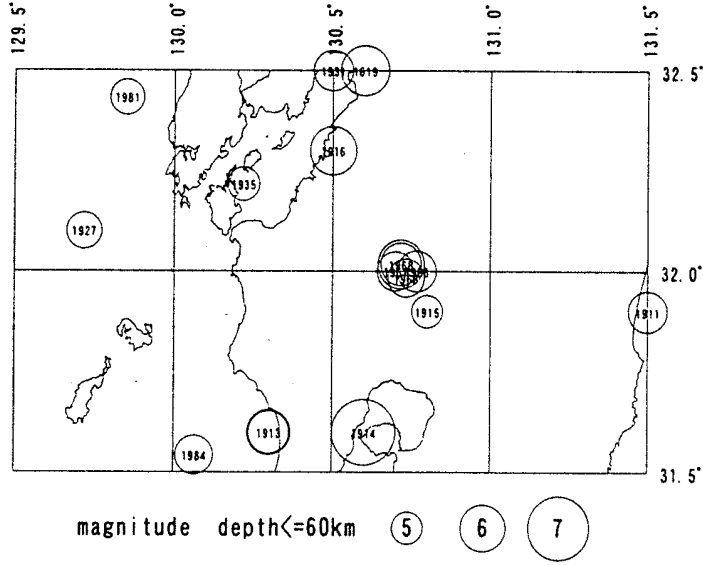

図2 400年〜1990年の $M>5$ の地震の震源位置

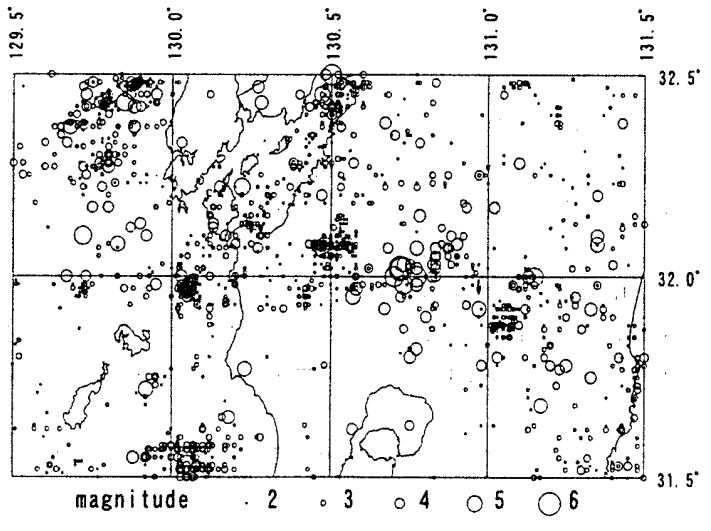

図3 1926年〜 1996年6月の地震の震源位置

\section{1 水平地震動の軌跡と計測震度}

3 月 26 日と 5 月 13 日の地震について、気象庁と科学技術庁の強震計 の水平加速度の軌跡と計測震度を図 4 と図5に示寸。震度の図の○印 は震央位置で、水平加速度の図の太い線は推定断層位置を示す。

震源の南東側に位置する被害の大きかった宮之城の計測震度は3 月26日の地震では気象庁の観測点では5.4、科学技術庁の観測点で は5.5で、5月13日の地震では気象庁の観測点では5.4、科学技術庁 の観測点では5.9である゙：計測震度と最大水平加速度とはほぼ対応 しているが、3月26日の科学技術庁の阿久根と出水は対忘していな い。これは後で示すように阿久根は長周期成分が卓越し、出水は短 周期成分が卓越しているためと考えられる。

3月 26 日の推定断層と水平加速度の軌跡を見ると断層方向に位置 する阿久根と宫之城では断層と直交する方向が大きく、反対に断層 方向と直交する位置する出水と川内では断層方向に大きく振動して いる傾向が見られる。5月13日の推定断層はL字になっているが、 大きく振動している方向は3月26日とほぼ同じ方向である。これは 東西方向の主断層の影響が大きいためと考えられる。

\section{2 地震動の最大加速度と距離隇衰曲線}

今回の地震では震源付近で多くの地震動が記録された。震源を囲 む科学技術庁の宮之城、川内、阿久根、出水の 4 地点で最大加速度 が大きい地震動の最大加速度を表 3 に示す。気象庁の宮之城、川内、 阿久根の 3 地点で最大加速度が大きい地震動の最大加速度を表 4 に 示す。3月26日の地震での出水の727 $\left(\mathrm{cm} / \mathrm{s}^{2}\right)$ p5月13日の地震での宮 之城の $902\left(\mathrm{~cm} / \mathrm{s}^{2}\right)$ と大きな最大加速度が記録された。過去の地震被 


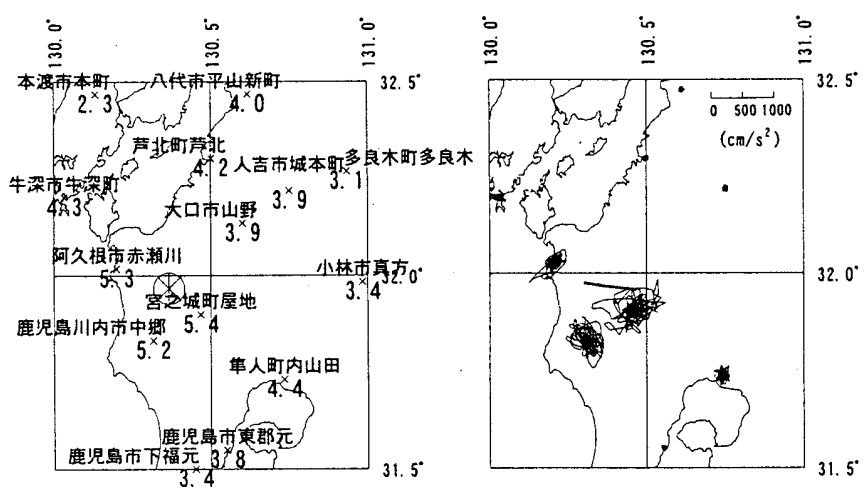

（a）気象庁の観測地点
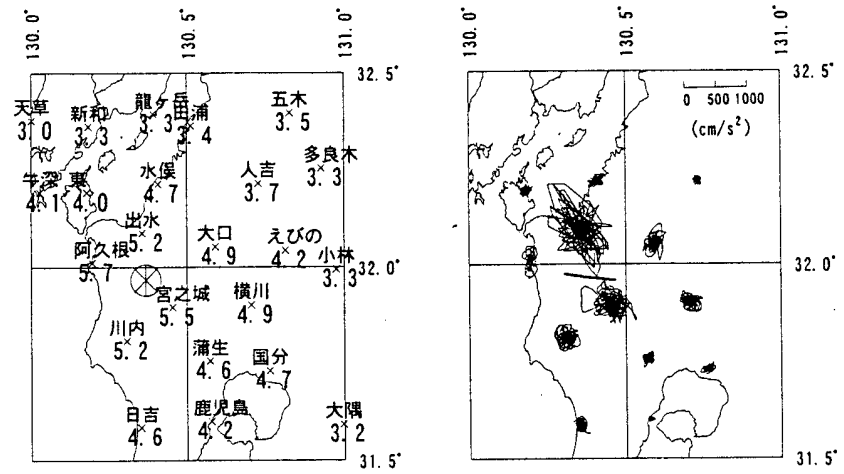

(b) 科学技術庁の観测地点

図43月26日の水平加速度の軌跡と計測震度

表 3 科学技術庁の観測点の最大加速度 $\left(\mathrm{cm} / \mathrm{s}^{2}\right)$

\begin{tabular}{|c|c|c|c|c|c|c|c|c|c|c|c|c|c|c|c|}
\hline \multicolumn{2}{|c|}{ 発生時刻 } & \multirow[b]{2}{*}{ M } & \multirow{2}{*}{$\begin{array}{c}\text { 梁 } \\
\mathrm{e} \\
\mathrm{km}\end{array}$} & \multicolumn{3}{|c|}{ 宮之城 } & \multicolumn{3}{|c|}{ 川 内 } & \multicolumn{3}{|c|}{ 阿久根 } & \multicolumn{3}{|c|}{ 出 水 } \\
\hline 月 日 & 時 間 & & & NS & $\mathrm{EW}$ & UD & $\mathrm{NS}$ & EW & UD & NS & EW & UD & NS & $\mathrm{EW}$ & $\mathrm{UD}$ \\
\hline 月26日 & 分 & 6.5 & 12 & 434 & 498 & 46 & 211 & 224 & 111 & 293 & 431 & 96 & 727 & 542 & 246 \\
\hline 月 26 日 & 17時39分 & 7 & 8 & 163 & 142 & 34 & 63 & 48 & 31 & 31 & 34 & 24 & 191 & 99 & 28 \\
\hline 月 26 日 & 分 & a & 10 & 211 & 38 & 44 & 75 & 39 & 16 & 20 & 18 & 11 & 32 & 0 & 14 \\
\hline 月 26 日 & & & 1 & 232 & 113 & 81 & 22 & 21 & 31 & 13 & 13 & & 18 & 11 & \\
\hline 月 26 日 & & & 10 & & 0.1 & & & & & & & & & 1 & \\
\hline 月26日 & 分 & & 1 & 132 & 49 & 50 & & & & 25 & 17 & 10 & 55 & 48 & 23 \\
\hline 月 27 日 & 19分 & 4.1 & 0 & 188 & 77 & 38 & - & - & - & 16 & 13 & 6 & 19 & 16 & 10 \\
\hline 月 1 日 & 2時14分 & 4 & 10 & 96 & 71 & 26 & - & - & 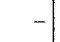 & 5 & & & 8 & 9 & \\
\hline 4月 3日 & 寺33分 & 5.5 & 9 & - & - & - & 124 & 179 & 50 & 98 & 112 & 70 & & & \\
\hline 4月 4 日 & 3分 & 4 & 10 & - & - & - & 24 & 27 & 1 & 25 & 19 & 11 & 112 & 56 & 22 \\
\hline 4月 5 日 & 4分 & & 8 & - & - & - & 93 & 0 & 42 & 50 & 39 & 9 & 120 & 72 & 50 \\
\hline 4月 9日 & 0分 & 9 & 10 & 266 & 30 & 98 & 51 & 5 & 20 & 59 & 38 & 3 & 61. & 79 & 28 \\
\hline 5月 13 日 & 8分 & 6 & 9 & 902 & 901 & 288 & 300 & 318 & 149 & 156 & 125 & 100 & 728 & 443 & 189 \\
\hline 5月 14 日 & 32分 & 4.7 & 10 & 141 & 182 & 38 & 57 & 34 & 18 & 29 & 11 & 1 & 40 & 40 & 10 \\
\hline 5月 25 日 & 6時11分 & 4.4 & 10 & 201 & 211 & 63 & 57 & 35 & 14 & 19 & 14 & 12 & 32 & 42 & 15 \\
\hline 月27日 & 14時14分 & 4.1 & 10 & 80 & 82 & 80 & 13 & 13 & 12 & 3 & 3 & & 19 & 13 & \\
\hline
\end{tabular}

表 4 気象庁の観測点の最大加速度 $\left(\mathrm{cm} / \mathrm{s}^{2}\right)$

\begin{tabular}{|c|c|c|c|c|c|c|c|c|c|c|c|c|}
\hline \multicolumn{2}{|c|}{ 発生時刻 } & \multirow[b]{2}{*}{$\mathrm{M}$} & \multirow{2}{*}{$\begin{array}{c}\text { 深 } \\
\mathrm{km}\end{array}$} & \multicolumn{3}{|c|}{ 宮之城 } & \multicolumn{3}{|c|}{ 川 内 } & \multicolumn{3}{|c|}{ 阿久根 } \\
\hline 月 日 & 時 間 & & & NS & EW & UD & NS & $\mathrm{EW}$ & UD & NS & $E W$ & $\mathrm{UD}$ \\
\hline 3月 26日 & 17時31分 & 6.5 & 12 & 491 & 663 & 393 & 435 & 364 & 128 & 305 & 397 & 131 \\
\hline 4月 3 日 & 4時33分 & 5.5 & 9 & 280 & 223 & 170 & 233 & 296 & 82 & 194 & 382 & 94 \\
\hline 4月 5 日 & 13時24分 & 4.9 & 10 & 239 & 278 & 197 & 311 & 265 & 32 & 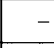 & 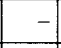 & - \\
\hline 5月 13日 & 14時38分 & 6.3 & 9 & 354 & 298 & 321 & 413 & 470 & 189 & 299 & 214 & 173 \\
\hline
\end{tabular}

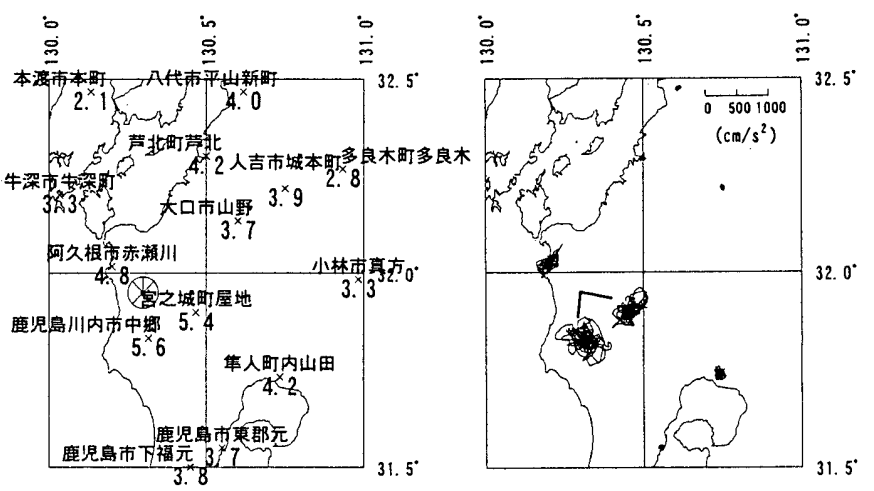

（a）気象庁の観測地点
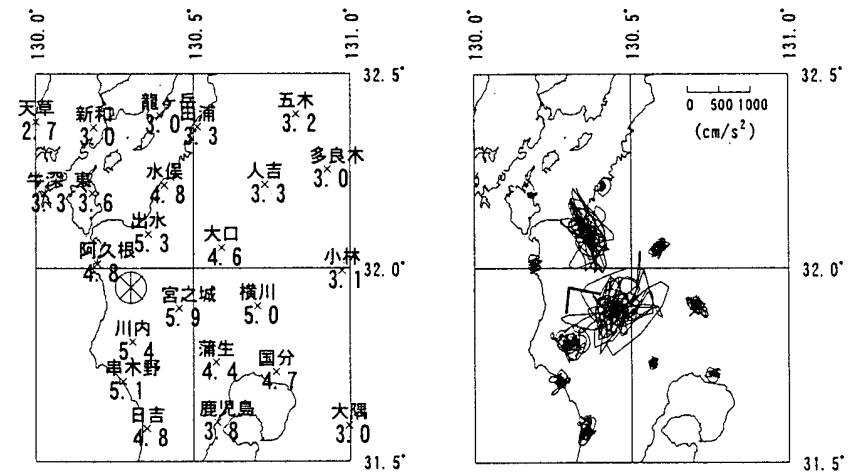

(b) 科学技術庁の観測地点

図5 5月13日の水平加速度の軌跡と計測震度

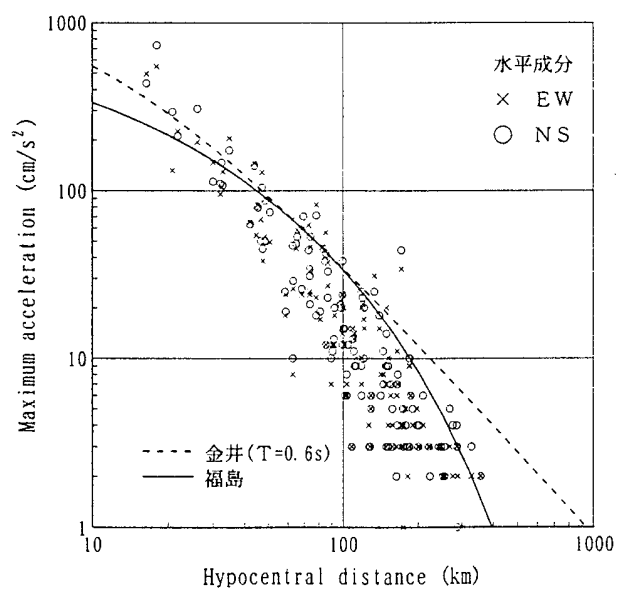

(a) 3月26日の地震

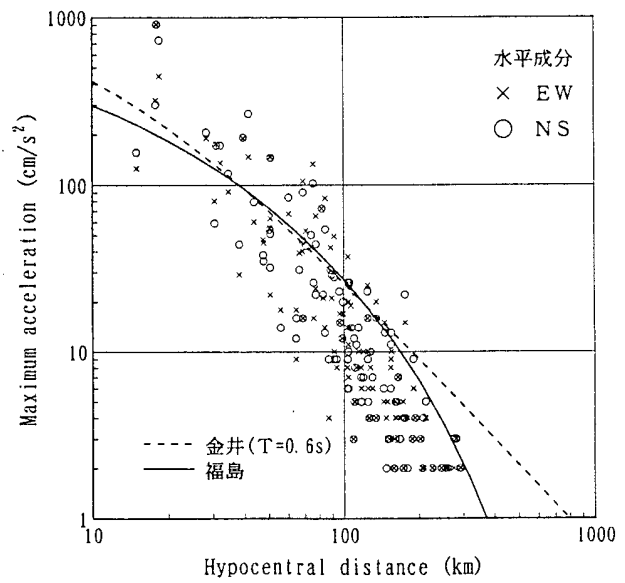

(b) 5月13日の地震

図6 科学技術庁の観測值と減衰曲線との比較 
害と最大加速度の関係から判断すると最大加速度の大きさの割には 表2の被害は小さいように思われる。2つの強震計の特性はSMAC型 強震計の特性とは同じでなく、高振動数まで感度が低下しないため 過去の記録と比べて最大加速度が大きいと考えられる。そこで、2 つの地震の科学技術庁の強震計による水平動の最大加速度の減衰曲 線を図6に示す。実線は福島の減衰曲線”で、点線は卓越周期を 0.6 (s)とした金井の減衰曲線")である。震源距離が30～80 (km) までの記 録をみるとばらつきは大きいが福島の減衰曲線や金井の減衰曲線と は良い相関が見られる。この範囲では今回の強震記録も過去の地震 動の特性とは大きく違っていないが、震源距離が $30(\mathrm{~km})$ 以下の記録 は減衰曲線より観測値が大きい傾向が見られる。これだけで過去の 地震の特性と異なるとは断定できないが、強震計の短周期成分の感 度が良いために大きな加速度が記録されたことは考えられる。

\section{3 宮之城町の地震動}

宮之城町の中心部は川内川による盆地の中にある。役場の平坦な 敷地に気象庁の強震計(宮之城屋地)が設置され、それより南東の傾 斜地を切り土した敷地に科学技術庁の強震計 (KGS005) が設置されて いる。強震計と大破の被害を受けた学校の位置を図 7 に示す。

宮之城町とその北東に位置する鶴田町の住家の被害を表 5 に示す。 3月 26日の地震では断層の終端に近い鶴田町の被害が大きく、5月13 日の地震では宮之城町の被害が大きいことが分かる。3月26日の地 震で断層の延長上にある鶴田町の鶴田小の特別教室棟が大破した。 宮之城農業高校は3月26日の地震では体育館が大破し、校舎も大破 の被害が受け、5月13日の地震で被害が拡大した。宮之城高校は3月 26日の地震では微小な被害であったが5月13日の地震で特別教室棟 が大破した。盈進小学校は3月26日の地震で校舎が中破の被害を受 け、5月13日の地震で被害が拡大して大破と判定された。

気象庁の 3 月 26 日の強震記録と減衰定数 $\mathrm{h}=5 \%$ の态答スペクトルを 図8に、5月13日の值を図9に示す。最大加速度は3月26日の方が大き く、特に、E-W方向で大きいのは断層の破壊がこの地点の北側を進 行したことと $0.2(\mathrm{~s})$ 以下の短周期成分が卓越しているためと考えら れる。固有周期 $\mathrm{T}=0.5 \sim 1.0$ (s) の水平動の速度応答スペクトルをみ

表5 宮之城町と鶴田町の住家の被害棟数

\begin{tabular}{|l|r|r|r|r|r|r|}
\hline & \multicolumn{3}{|c|}{ 3月26日〜4月9日 } & \multicolumn{3}{|c|}{ 5月13日 } \\
\cline { 2 - 7 } & 全壊 & 半壊 & 一部破損 & 全壊 & 半壊 & 一部破損 \\
\hline 宮之城町 & 0 & 0 & 433 & 2 & 12 & 1,001 \\
\hline 鶴田町 & 2 & 11 & 1,389 & 0 & 4 & 480 \\
\hline
\end{tabular}

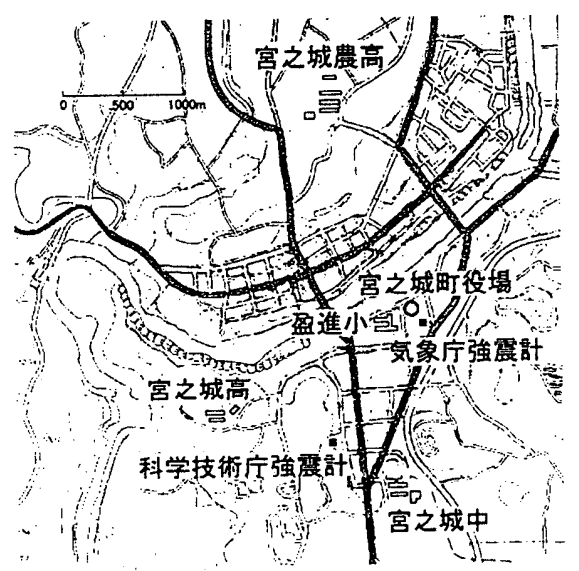

図 7 宮之城町の強震計 ( $\mathbf{(}$ 印) と大破した学校の位置
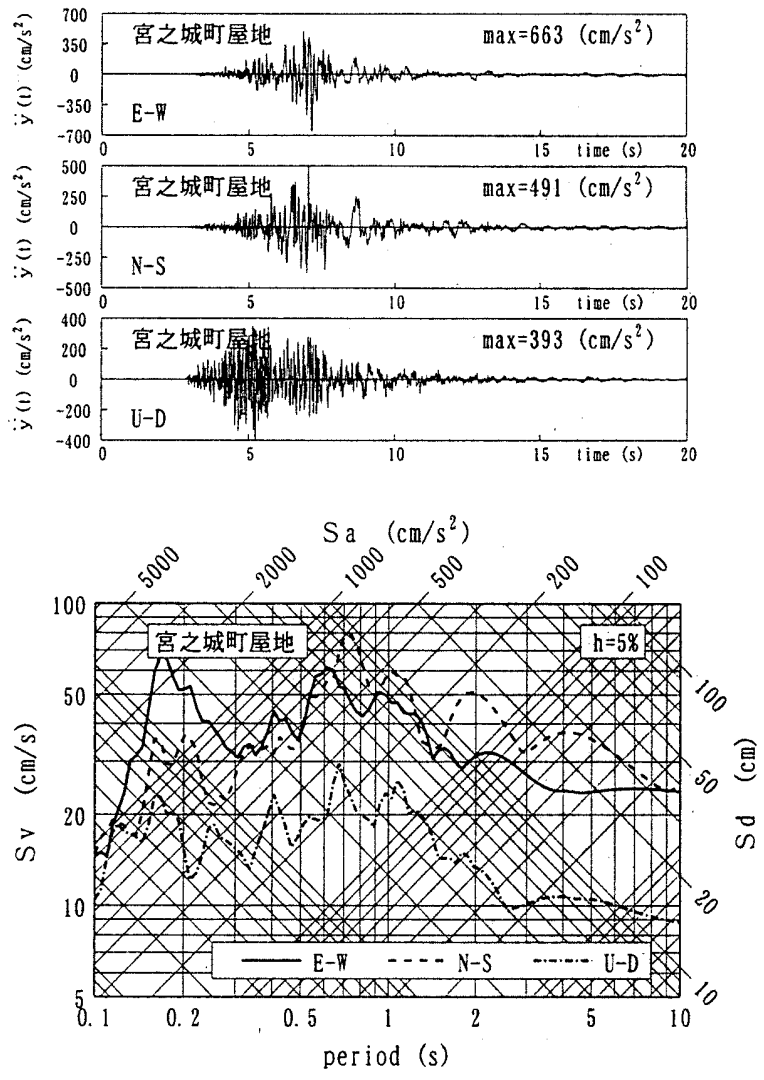

図8 宮之城町の3月26日の気象庁の地震動と応答スペクトル
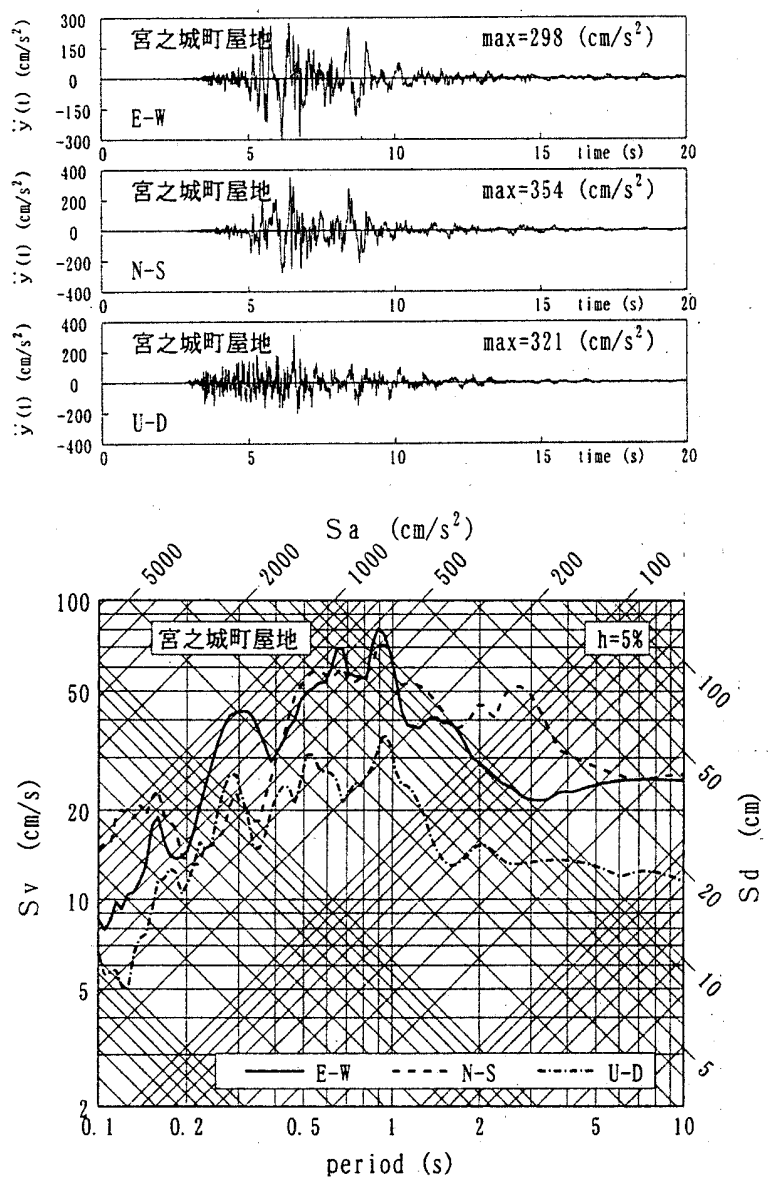

図9 宮之城町の5月13日の気象庁の地震動と态答スペクトル 

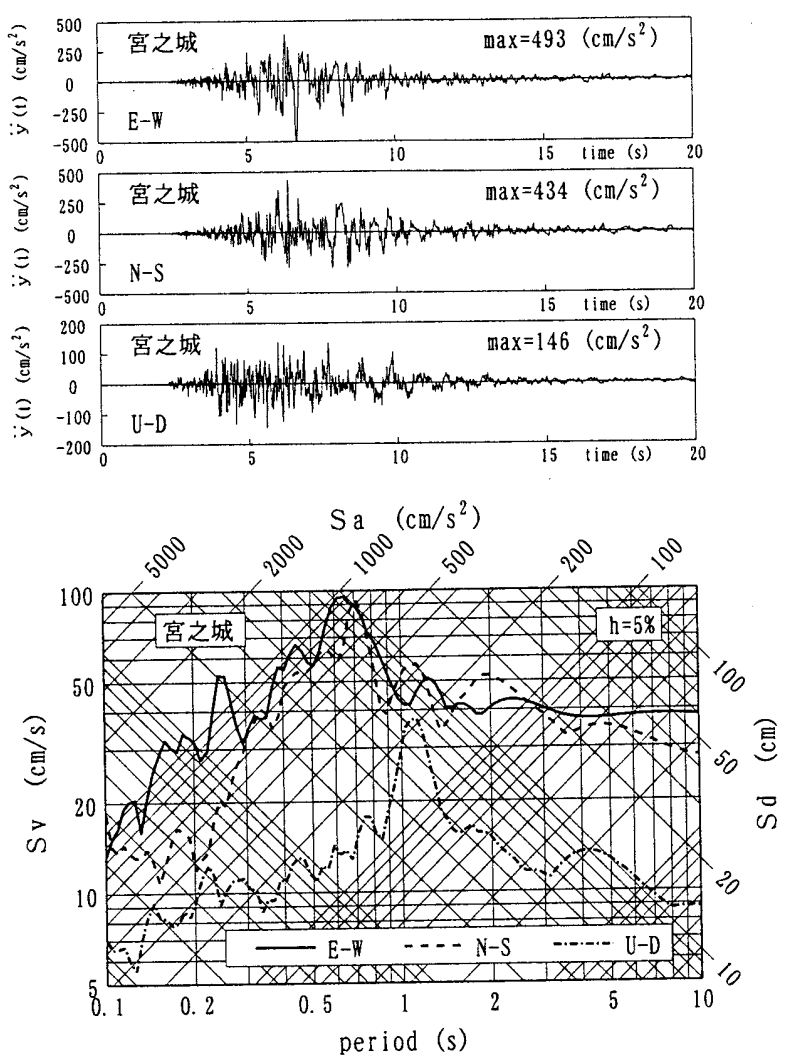

図10 宮之城町の3月26日の科学技術庁の地震動と応答スペクトル

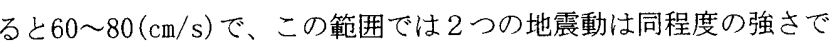
ある。これより短周期成分では3月 26 日の地震動が数倍大きく、こ れは震源が近いためと考えられる。

科学技術庁の 3 月 26 日の強震記録と $\mathrm{h}=5 \%$ の応答スペクトルを図 10 に、5月13日の値を図11に示す。最大加速度は地震規模が小さい 5 月 13 日の方が約 $900\left(\mathrm{~cm} / \mathrm{s}^{2}\right)$ と非常に大きかったが、これは0.3(s) 以下 の短周期成分が強いためである。5月13日の速度応答スペクトルを みるとE-W方向では $\mathrm{T}=0.3(\mathrm{~s})$ で $120(\mathrm{~cm} / \mathrm{s}) 、 \mathrm{~T}=0.65(\mathrm{~s})$ で $150(\mathrm{~cm} / \mathrm{s})$ と非常に大きな值を示している。一方、 $\mathrm{N}-\mathrm{S}$ 方向は $\mathrm{T}=0.65(\mathrm{~s})$ で70 $(\mathrm{cm} / \mathrm{s})$ で、3月26日の地震では両方向とも $90(\mathrm{~cm} / \mathrm{s})$ である。この地 震計の西約500 (m) の高台に5月13日に校舎が大破した宮之城高校が ある。3 階建て R C 造の特別教室棟の長辺方向は東西方向で、その 弾性 1 次固有周期は $0.216(\mathrm{~s})$ と推定されている ${ }^{100}$ 。強震計の敷地内 の両隣にある $2 つ の 1$ 層 R C 造の建物は無被害で、高校との間にあ る住宅も屋根瓦の破損程度の被害であることを考えると、以前の地 震で剛性が低下して0.3(s) 付近の強い地震動成分と共振して大破に 至ったと考えられる。

$2 つ$ 強震計は $1 \mathrm{~km}$ ほど離れているだけであるが、0.3(s) 以下の 短周期成分の特性は3月26日と5月13日では全く逆であった。これは 断層との位置関倸が影響していると考えられる。

4 つの強震記録とも上下動は水平動に比べると強さは半分以下と 小さかった。震央距灕が数 $\mathrm{km}$ 程度と近い場合は一般に上下動は大 きいことが多いが、後で示す他の 3 地点でもほぼ同じような関係が 見られるのでこれがこの地震の特性と思われる。

\section{4 阿久根市の地震動}

阿久根市は図 1 に示すように 3 月 26 日の地震は宮之城町とは震源
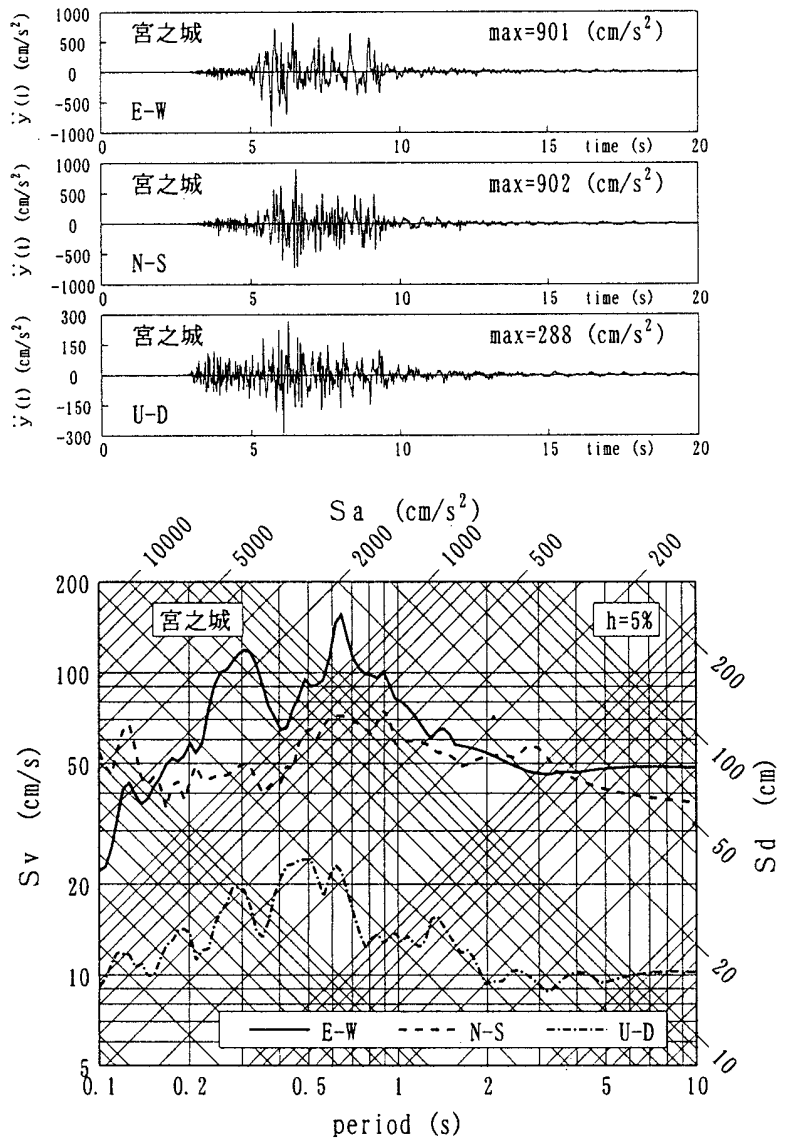

図11 宮之城町の5月13日の科学技術庁の地震動と応答スペクトル

の反対側に位置している。阿久根市の住家の被害を表 6 に示す。震 源域から離れているためか建物の被害は多くなかった。港の近くに ある市役所の敷地に科学技術庁の強震計 (KGS004)があり、それより $1.5 \mathrm{~km}$ 北側の岡の上にある気象台に強震計 (阿久根市赤瀬川) が設置 されている。

2 つの強震記録とも3月26日の地震動の方が5月 13 日の地震動より 大きい。そこで、気象庁の 3 月 26 日の強震記録と $\mathrm{h}=5 \%$ の応答スペク トルを図12に、科学技術庁の 3 月 26 日の強震記録と $\mathrm{h}=5 \%$ の答スペ クトルを図13に示す。

科学技術庁の水平地震動特にN-S方向にはピークを過ぎた後に長 周期の波が明瞭に表れている。応答スペクトルを見ると $1.5(\mathrm{~s})$ 付近 に強いピークが見られる。この地点は18mまで $\mathrm{N}$ 值が10以下の軟弱 な地盤で、強震計の近くの港の埋め立て地には規模は小さいが憤砂 の跡が観察されているので、この長周期の波は地盤が液状化したた めと考えられる。2つの水平動は大きさと波形がかなり異なってい るが、これは西側に川を挟んで南北方向の崖があることによる地形 の影響が表れている可能性が高い。

気象庁の地震動は 2 方向の水平動はよく似た傾向を示している。 この地点でも1.2(s) 付近にピークが見られ、科学技術庁のN-S成分 と特性が似ている。0.17(s) 付近の成分が卓越しているが、これは 表 6 阿久根市住家の被害棟数"

\begin{tabular}{|l|r|r|r|r|r|r|}
\hline \multirow{2}{*}{} & \multicolumn{3}{|c|}{3 月 26日 4月9日 } & \multicolumn{3}{|c|}{ 5月13日 } \\
\cline { 2 - 7 } & 全壊 & 半壊 & 一部破損 & 全壊 & 半壊 & 一部破損 \\
\hline 阿久根市 & 2 & 5 & 193 & 0 & 0 & 43 \\
\hline
\end{tabular}



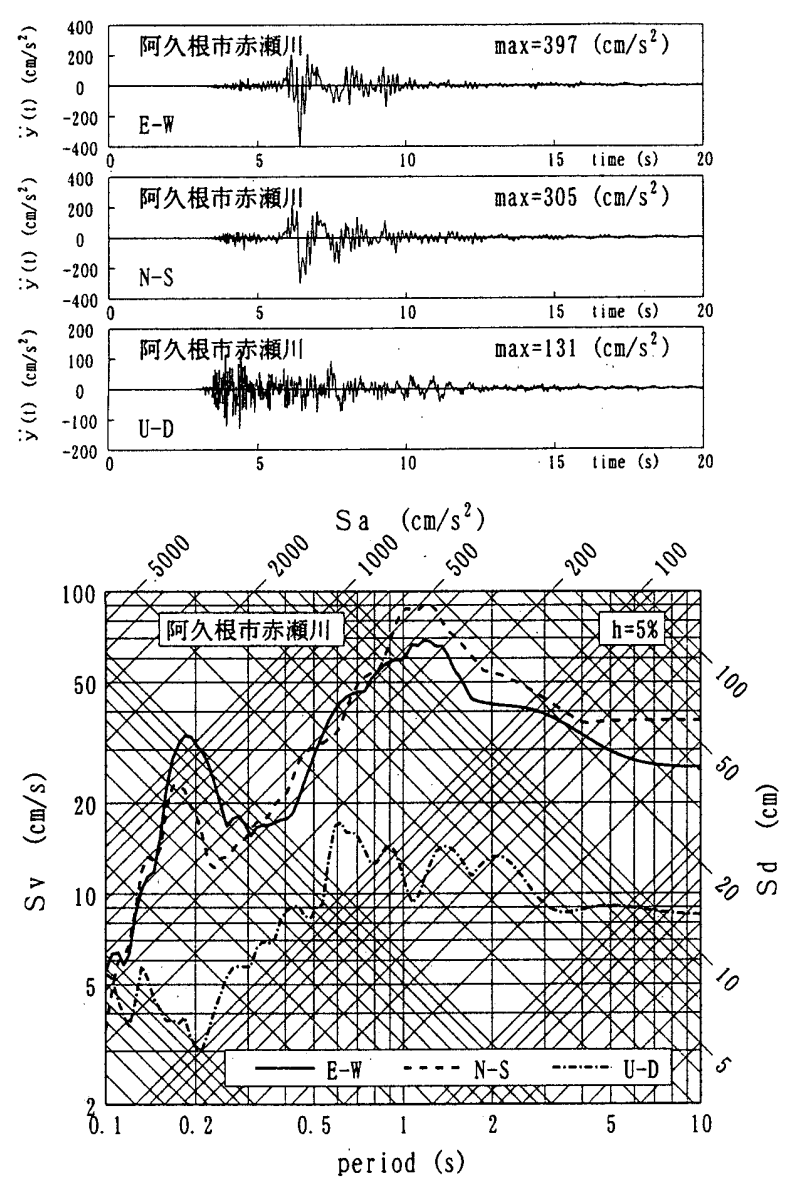

図 12 阿久根市の 3 月 26 日の気象庁の地震動と忘答スペクトル

常時微動観測でも見られるので地盤の特性と考えられる。

ここには図は示していないが、5月13日の科学技術庁の強震記録 には1.5(s)の成分は卓越していない。地震の規模が小さいの之震源 からの距離が大きくなったので夜状化が生じなかったためであろう。 気象庁の記録では1.2(s)の成分は少し卓越しているが0.17(s)の成 分と同程度の大きさである。

3月26日の地震は断層の中央で破壊が始まり、東西に破壊したと 見られているが、東側の宮之城と西側の阿久根の地震動には共通的 な特性は見られず、震源距離と地盤・地形の影響が大きい。

\section{$4: 5$ 川内市の地震動}

川内市は川内川の河口にあり、2つの震源の南側に位置している。 強震計のある市街地は3月26日の地震の断層とは直交方向に位置し、 5 月 13 日の地震では 1 つの断層の方向に位置する。川内市とその東 側に位置する東郷町の住家の被害を表 7 に示す。北部では3月26日 にも被害を受けたが市街地付近は5月13日の被害が大きかった。

ここには、市役所に隣接する敷地に科学技術庁の強震計 (KGS007) が、それより $500(\mathrm{~m})$ 程北側にある公園に気象庁の強震計（鹿児島川 内中郷)が設置されている。いずれも川内川の近くで平坦な敷地で ある。両者とも最大加速度は5月13日の方が3月26日より少し大きい。

表 7 川内市と東郷町の住家の被害棟数 ${ }^{21}$

\begin{tabular}{|c|r|r|r|r|r|r|}
\hline \multirow{2}{*}{} & \multicolumn{3}{|c|}{3 月26日 年9日 } & \multicolumn{3}{|c|}{ 月月13日 } \\
\cline { 2 - 7 } & 全壊 & 半壊 & 一部破損 & 全壊 & 半壊 & 一部破損 \\
\hline 川内市 & 0 & 8 & 148 & 2 & 10 & 2,648 \\
\hline 東郷町 & 0 & 0 & 47 & 0 & 0 & 496 \\
\hline
\end{tabular}
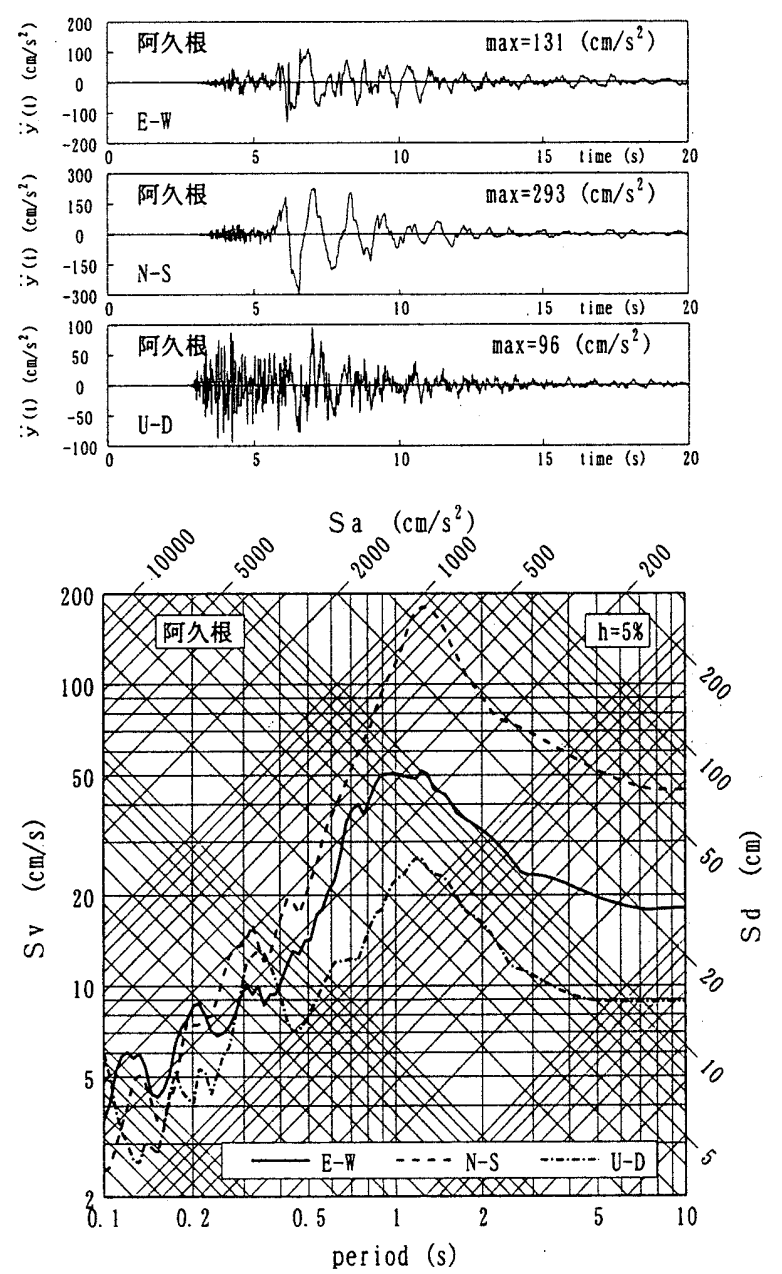

図13 阿久根市の3月26日の科学技術庁の地震動と応答スペクトル

そこで、気象庁の5月13日の地震動と $\mathrm{h}=5 \%$ の応答スペクトルを図 14 に、科学技術庁の 5 月 13 日の地震動と $\mathrm{h}=5 \%$ 応答スペクトルを図 $15 に$ 示す。

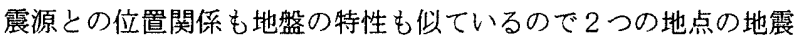
動もその応答スペクトルもよく似ている。E-W方向では $\mathrm{T}=0.75(\mathrm{~s})$ にピークが見られ、応答スペクトルは $120(\mathrm{~cm} / \mathrm{s})$ と大きい。短周期 成分はそれほど大きくない。一方、N-S方向では科学技術庁の記録 には $\mathrm{T}=1.5(\mathrm{~s})$ 付近にピークが見られるが、気象庁の記録にはピー クは見られない。E-W方向が強いのは断層との位置関係が関倸して いると考えられる。

図には示していないが3月26日の地震動は気象庁のE-W方向に0.75 (s) 付近の成分が卓越していない点を除けば、全体としては地震動 の波形もスペクトルの特性も5月13日の特性とよく似ている。

このように、比較的地形・地盤特性が似ている地点では地震動の 大きな傾向は似ているが、卓越周期などの詳細なスペクトルの特性 では異なった点が見られる。これは震源に近いためにその影響が大 きいためと考えられる。

表 8 出水市の住家の被害棟数 ${ }^{2}$

\begin{tabular}{|l|r|r|r|r|r|r|}
\hline \multirow{2}{*}{} & \multicolumn{2}{|c|}{ 3月26日〜4月9日 } & \multicolumn{3}{|c|}{ 5月13日 } \\
\cline { 2 - 7 } & 全壊 & 半壊 & 一部破損 & 全壊 & 半壊 & 一部破損 \\
\hline 出水市 & 0 & 1 & 67 & 0 & 0 & 13 \\
\hline
\end{tabular}




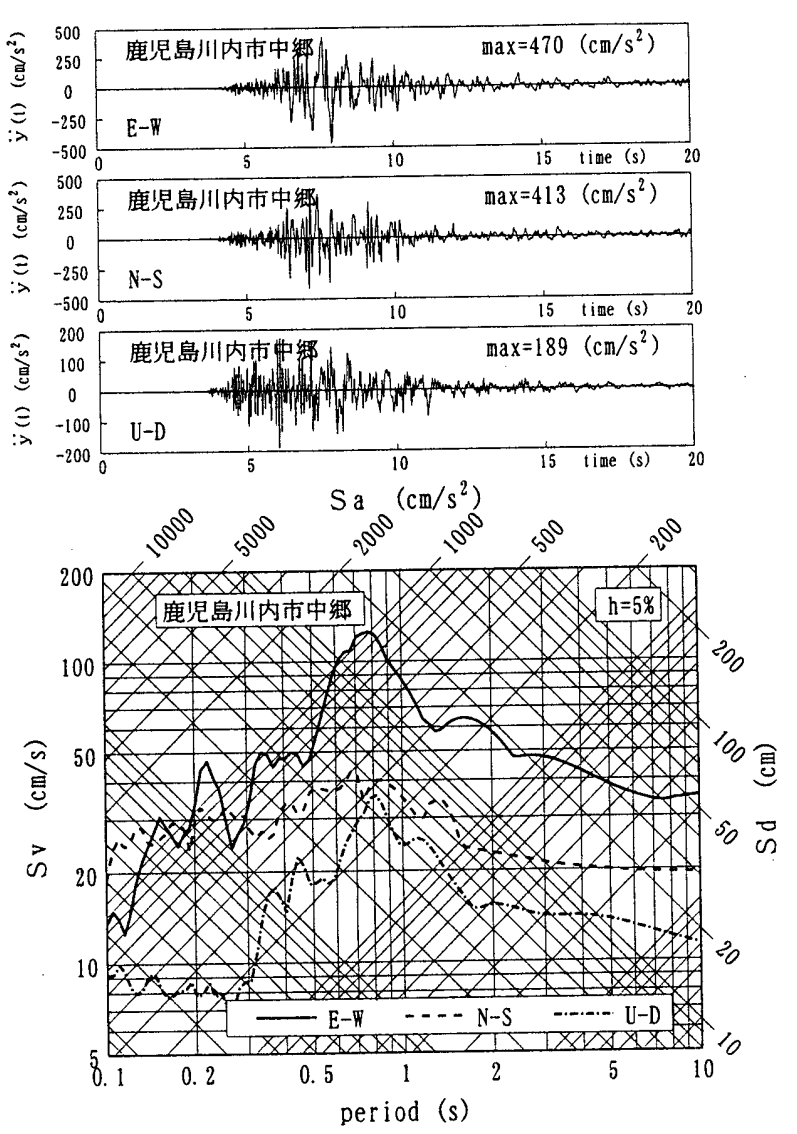

図14 川内市の5月13日の気象庁の地震動と応答スペクトル
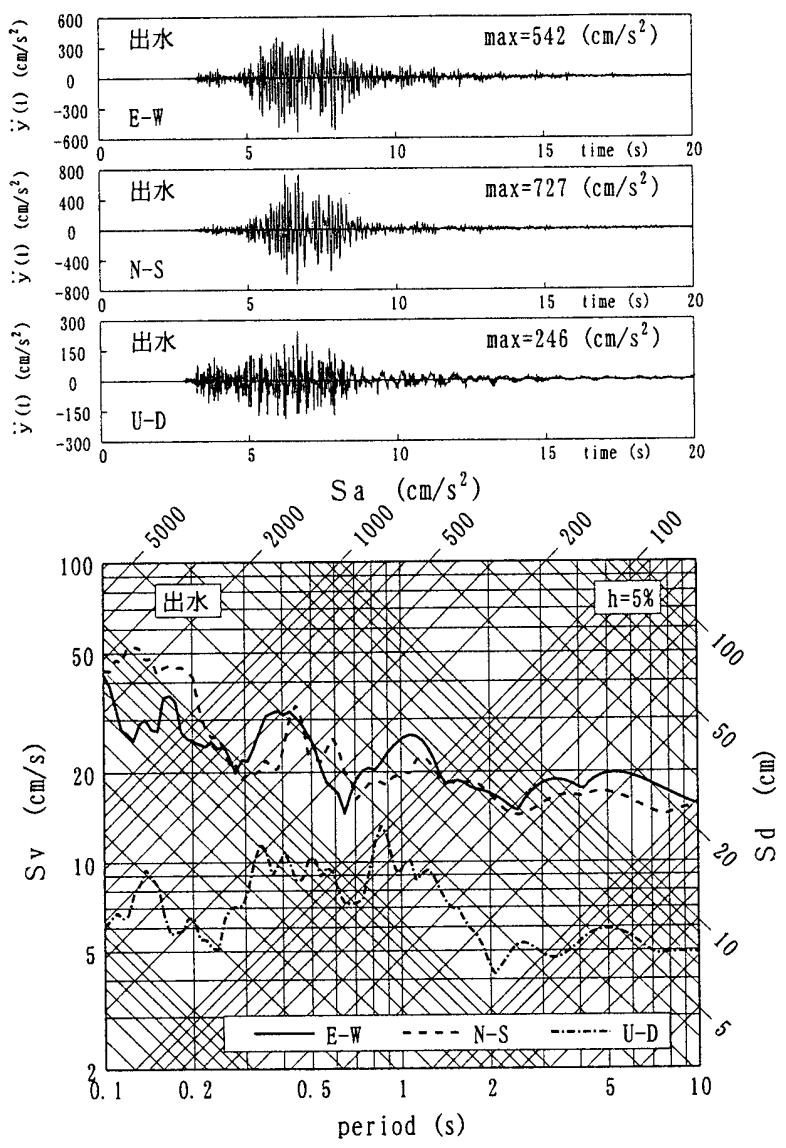

図16 出水市の3月26日の科学技術庁の地震動と応答スペクトル

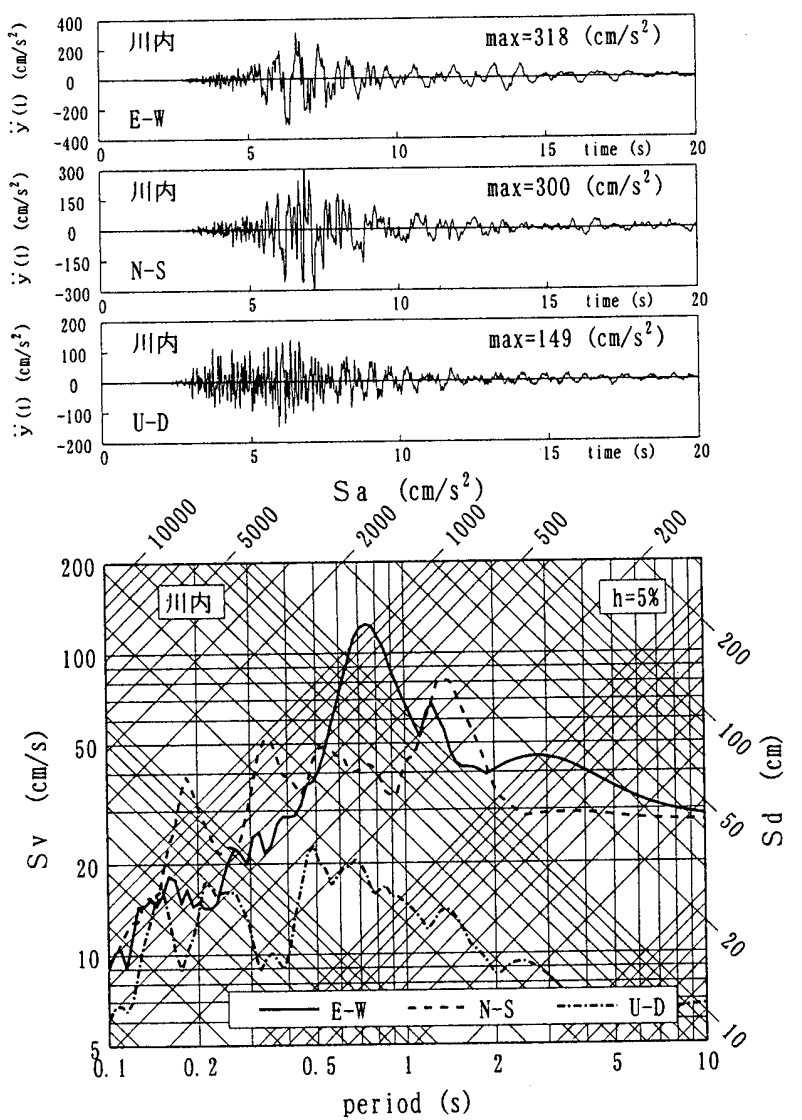

図15川内市の5月13日の科学技術庁の地震動と応答スペクトル

\section{6 出水市の地震動}

出水市は $2 つ の$ 震源の北側に位置している。出水市の住家の被害 を表 8 に示す。3月26日の地震も5月13日の地震でも一部の建物の被 害はあったが全体的に見れば被害は小さかった。

ここには、市役所の平坦な敷地に科学技術庁の強震計(KGS002)が 設置されている。3月26日の強震記録と $\mathrm{h}=5 \%$ の応答スペクトルを図 16に示す。図に示していない5月13日の地震動はE-W方向で0.2(s) か ら0.5(s)の成分が小さくなっているのを除けばよく似ている。最大 加速度が727 (cm/ $\left.\mathrm{s}^{2}\right)$ であるN-S方向の态答スペクトルをみると、 $\mathrm{T}=$ 0.2 (s) 以下の短周期成分が非常に大きいことが分かる。地盤は6 (m) の位置で、N值が50で、せん断波速度が500(m/s) である固い地盤で ある。常時微動観測によれば0.08(s)にピークがあるので、短周期 成分が卓越するのは地盤の影響と考えられる。逆に、0.2(s) 以上の 応答スペクトルは20 30 $(\mathrm{cm} / \mathrm{s})$ 程度でそれほど大きくない。強震計 のそばの市役所や倉庫の建物に被害が見られなかったのは建物が共 振する地震動の成分は大きくなかったためと考えられる。

\section{5. 結論}

1997年鹿児島県北西部地震は震度の測定が計測震度に変更になっ て始めての大きな被害を受けた地震であった。そのために高密度に 設置された科学技術庁と気象庁の強震計により、大都市ではないに も拘わらず、過去に例のない震源近傍の多くの貴重な強震記録が得 られた。

震源付近で大きな最大加速度が得られたが、震源距離 $30 \sim 80(\mathrm{~km})$ では過去のデータから推定された金井や福島の減衰曲線とほぼ一致 
する。それより近距離では観測值の方が大きい傾向がある。これは 強震計の特性が短周期まで感度が高いことも影響していると考えら れる。

震源を取り囲む東西南北 4 地点の強震記録が得られたが、大局的 には断層の破壊方向に位置する地点の地震動江直交方向に大きく振 動し、断層と直交方向に位置する地点の地震動は断層方向に大きく 振動する特性を示しているなど断層との位置関係が大きな影響があ ることが分かった。

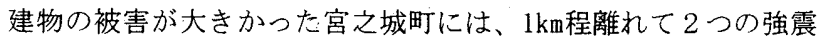
計があったが、建物の被害分布と対応するように、北側にある気象 庁の地震動は3月26日の方が強く、南側の科学技術庁の地震動は5月 13日の方が強かった。また、これらの大きな地震動には短周期成分 が強いことが分かった。これらは断層との位置関係の違いが反映し ていると考えられる。

阿久根の3月26日の科学技術庁の地震動には液状化によるものと 考えられる1.5(s)の卓越周期が含まれていることが分かった。断層 の中央から破壊した3月26日の震源の反対側にある宮之城と阿久根 の地震動を比較すると、共通的な特性は少なく、地形や地盤の影響 の方が大きかった。

地盤条件が似ていると思われる川内の 2 つ強震記録は大きな特 性は似ているがスペクトル特性の詳細は地震動毎に違っている。

3月26日の出水では727 (cm/s $\left.\mathrm{s}^{2}\right) 、 5$ 月13日の宮之城では $902\left(\mathrm{~cm} / \mathrm{s}^{2}\right)$ など大きな最大加速度を記録したが強震計のすぐそばにあった建物 には殆ど被害がなかった。同じような例は、既に、1993年北海道南 西沖地震の余震 (M=6.5) で乙部町で観測された $\mathrm{E}-W=1586 、 \mathrm{~N}-\mathrm{S}=397$ 、 U-D $=576\left(\mathrm{~cm} / \mathrm{s}^{2}\right)$ で強震計付近の建物に大きな被害がなかったとの報 告 ${ }^{11}$ 、1993年釧路沖地震 $(M=7.8$, 震源深さ $=100 \mathrm{~km})$ で釧路気象台でN-
$\mathrm{S}=817, \mathrm{E}-\mathrm{W}=922, \mathrm{U}-\mathrm{D}=466\left(\mathrm{~cm} / \mathrm{s}^{2}\right)$ で強震計の周辺での建物に大きな被 害がなかったとの報告 ${ }^{22}$ がある。出水などの地震動を見ると、震源 に近い地震動の場合には短周期成分が非常に卓越しているため最大 加速度は大きいが、構造物の 1 次固有周期での成分は高くないため と考えられる。このような大きな加速度と建物の被害との関倸は今 後の研究課題であろう。

\section{参考文献}

1) 日本建築学会九州支部，「1997年鹿児島県北西部地震災害調査報告」， 1998年3月

2) 鹿児島県消防防災課、「鹿児島県薩摩地方を震源とする地震災害状況」

3) 宇佐美龍夫，「新版 日本地震被害総覧」，東京大学出版会

4)大沢胖, 村上雅也, 西川孝夫, 「1968年2月21日および22日の宮崎県飯盛山付 近の地震 (えびの地震) による家屋被害」，地震研究所骨報、Vol.46, 1968

5) 気象庁、「震度を知る」: ぎょうせい、1996

6)科学技術庁ホームベージ(文献13)を参照)

7) 東京大学地震研究所ホームベージ(文献14)を参照)

8)福島美光, 「断層近傍まで適用可能な最大加速度の距嶉减衰式の導出と改 訂」，清水建築研究報告, 第63号, 1996年

9) 金井清, 「地震工学」, 共立出版

10) 中村友紀子他、「1997年鹿児島県北西部地震による被害建物の地震応答 解析」，第 2 回都市直下地震災害総合シンボジウム論文集, 1997

11) Kazuyoshi Kudo 他亏名, "Effects of Surface Soil and Earthquake

Source Radiation on the Ground Motion of $1.6 \mathrm{~g}$ Acceleration,

Observed During the August 8,1993, South-west of Hokkaido

Earthquake, Japan”，第9回日本地震工学シンボジウム, 1994

12)杉村義広 他 7 名,「平成万年䤲路沖地震における地震記録とその建物破壊 力の検証」，建築研究報告, No. 134, 1996

また、以下のインターネットのデータを利用しました

13) 科学技術庁防災科学研究所の強震データ (ht tp://Www. k-net. bosai.go. jp /k-net_docs/text/kyoshin. html)

14) 東京大学地震研究所 計測震度 (ht tp://t ibet. eri.u-tokyo. ac. jp/info/ shindo. $h \mathrm{tml}$ )

15)九州大学理学部島原地震火山観測所 (ht tp: //www. sevo. kyushu-u. ac. jp) 